\title{
СЕМАНТИКА І ПРАГМАТИКА ПОРІВНЯННЯ: ЙОГО МОВНІ І МОВЛЕННСВІ ФУНКЦЇ̈ В ЛІНГВОКРЕАТИВНІЙ КОМУНІКАТИВНІЙ ДІЯЛЬНОСТІ
}

\author{
ОКСАНА МОЛЧКО \\ Львівський національний університет імені Івана Франка, Львів - Україна \\ SEMANTYKA I PRAGMATYKA PORÓWNANIA: \\ JEGO FUNKCJE JEZZYKOWE W LINGWOKREATYWNEJ \\ DZIAŁALNOŚCI KOMUNIKACYJNEJ
}

\section{OKSANA MOŁCZKO}

Lwowski Państwowy Uniwersytet imienia Iwana Franki, Lwów — Ukraina

STRESZCZENIE. W artykule zaprezentowana została specyfika porównania z uwzględnieniem postulatów filozofii lingwistycznej, w szczególności przeanalizowane zostały osobliwości natury znaczenia semantycznego i pragmatycznego, zaprezentowanych w porównaniu, scharakteryzowane funkcje, wykonywane przez porównanie w lingwokreatywnej działalności komunikacyjnej.

\section{SEMANTICS AND PRAGMATICS OF SIMILE: \\ ITS LINGUISTIC AND SPEECH FUNCTIONS \\ IN LINGUISTIC CREATIVE COMMUNICATIVE ACTIVITY}

\author{
OKSANA MOLCHKO \\ L'viv Ivan Franko National University, L'viv — Ukraine
}

ABSTRACT. The article highlights the specificity of simile from the point of view of the philosophy of language. In particular, it considers peculiarities of semantic and pragmatic meanings as represented in simile and characterizes the functions of simile in linguistic creative communication.

$\mathrm{K}$ атегорія порівняння - це складна лінгвофілософська категорія. Якщо iii розглядати крізь призму логіки, то зауважимо іiі операціональний ня довкілля. В обсяг порівняння входить і градуювання, що „як процес передує виміру й лічбі"', яким активно користується людина. Онтологічна іпостась порівняння закріпилася в мові як поняття однакового або більшого чи меншого ступеня вияву якості, тобто як поняття про тотожність і нетотожність предметів, явищ, довкілля.

Мовний простір, що репрезентує категорію порівняння, дуже широкий: він охоплює усі значеннєві рівні мови - від словотвірного до синтаксичного, виявляється в мовленні, що репрезентується в тексті (дискурсі).

${ }^{1}$ В. М. Огольцев, Устойчивые сравнения в системе русской фразеологии, Ленинград $1978,159 \mathrm{c}$.

2 Э. Сепир, Градуирование, [в:] Новое в зарубежной лингвистике. (Лингвистическая прагматика), Москва 1985, вып. 16, с. 43. 
Цю категорію деякі науковці розуміють дуже широко, кваліфікуючи іiі як універсальну категорію, виражену бінарною опозицією „подібне і неподібне", що є основою мовних опозицій загалом.

Системна організація інвентарю численних експлікаторів семантики порівняння, очевидно, ще цілком недосліджена. Однак на сьогодні зрозуміло, що структурно-семантична складність, усеохопність і неоднорідність цих засобів зумовлена розмаїттям їх функцій як у мові, так і в мовленні³.

Учені вважають, що при інтегративному підході основними функціями мовної одиниці слід уважати сукупність чотирьох: номінації, повідомлення, репрезентації відношень і залежностей, а також функції кваліфікації й оцінки а при диференційному - реєстр функцій розширюється, зокрема граматична форма може виконувати такі функції - семантико-морфологічні, семантикосинтаксичні, формально-синтаксичні, оцінювально-кваліфікаційні 5 . 3 факту лише перерахування функцій, які виокремили Н. Шведова і М. Шелякін, уже помітно використання складних найменувань й сурядних рядів, що свідчить про відсутність чіткого окреслення подібних класифікацій.

Загальноприйнятим розумінням функції мовної одиниці стосовно мовної системи $€$ призначення цієї одиниці виражати категоріальне значення.

Зовнішній (ментальний) аспект цієї функції - співвідношення концептуальної, понятійної картини світу з іiі мовним вираженням. 3 урахуванням зовнішньомовної функції різних рівнів мовної системи, напр. значення подібності може виражатися за допомогою словотвірних і синтаксичних засобів: лебедині руки - руки, схожі на лебедів.

Під мовленнєвою функцією розуміємо мету використання мовної одиниці у висловлюванні, ширше - в дискурсі, в конкретній мовленнєвій ситуації. Цілком можливо, що в конкретному висловлюванні мовна одиниця може бути використана в такій функції, для якої в системі конкретної мови вона може бути не пристосована й у певному використанні втрачає своє призначення, наприклад в певній ситуації можливими $є$ з першого погляду абсурдні фрази типу Добре - ие погано; Померти - значить залишитися жити, в яких мовленнєва ситуація, „діагностичний контекст” нейтралізує мовні відношення антонімії.

Якими ж є мовні й мовленнєві функції порівняння? Одна з основних екстралінгвістичних функцій порівняння — це вербалізація пізнання. Залежно від характеру операцій порівняння ця функція диференціюється на більш конкретні: 1) ідентифікувальна функція, тобто констатація подібності чи відмінності між предметами чи явищами, напр.: Дочка схожа / не схожа на матір; 2) функція репрезентації, яку здійснює предмет щодо окреслення класів інших однорідних предметів, напр.: На таких, як він, земля тримається; 3) градуювальна функція: вона полягає у визначенні ступеня якості одного об'єкта стосовно іншого чи інших предметів, напр.: Любов страшніма за ненависть; 4) градуювання може бути пов'язане з виокремленням об'єкта серед подібних як єдиного в своєму роді - це виокремлювальна функція порівняння, напр.: Єдина втіха - книжска; 5) порівняння може виконувати функцію корелювання маніфестувати відповідність чи невідповідність предмета до чогось, напр.: На вигляд орел, а за розумом - осел.

${ }^{3}$ С. О. Карцевский, Сравнение, [в:] „Вопросы языкознания”, 1976, № 1, с. 107-112.

${ }^{4}$ Н. Ю. Шведова, Один из возможных путей построения функииональной грамматики русского языка, [в:] Проблемы функиииональной грамматики, Москва 1985, с. 30-37.

${ }_{5}^{5}$ М. А. Шелякин, О единстве функиионального и системного описания грамматических форм в функииональной грамматике, Москва 1985, с. 118. 
Утім, найголовніше те, що кожний засіб порівняння виконує номінативну функцію: в широкому розумінні відображає денотативну структуру ситуації порівняння й результат цього порівняння. Ситуація $\mathrm{A}=$ Б за ознакою $n$ може бути репрезентована різними способами, напр.: На вроду дочка вся в батька. Дочка і батько дуже схожі: в них однакова врода. - Врода у дочки абсолютно така, як у батька. - Дочка на вроді усі риси батька відібрала і под. Незважаючи на відмінності в актуалізації компонентів компаративної структури, денотативна структура ситуації залишається незмінною: констатується схожість батька 3 дочкою на основі однієї ознаки - вроди. Пресупозиційне тло дає змогу в певних умовах назвати цю ситуацію і так: Справді, яблуко від яблуньки недалеко падає.

У вузькому розумінні номінативна функція порівняння (метафора - це різновид порівняння) виявляється в термінології: грудна жаба; сухоти; туберкульоз (назви хвороби).

Із екстралінгвістичною функцією вираження у всіх іï різновидах тісно пов'язана концептуальна функція порівняння, що репрезентує ідіоетнічну специфіку картини світу шляхом кореляції зображуваного предмета з іншими, близькими для певного мовного соціуму предметами чи їх образами, напр. порівняння обличчя дівчини з місяцем у казахів, iї норову до норову кобилиці у киргизів, порівняння волосся дівчини з льоном у білорусів і под.

Аналіз типових художніх порівнянь, як правило, досить чітко окреслюється в художній літературі, зокрема й у художніх перекладах, оскільки виникає необхідність моделювати мовну картину світу порівнянь в кожній окремо взятій лінгвокультурі, яка окреслює певний менталітет, що може проектуватися, наприклад, на сприйняття світу. Для українців - це світло, земля, вода, а для росіян у сприйнятті світу домінують категорії простір, повітря, безконечність. Земля для українця і $є$ його простір, до неї він прикладає руки, тому вона, як і вода, у межах його досяжності. Звідси і його ставлення до світу — тверезе, діяльне, таке, що не приймає агресії, виражає інтимне, ласкаве ставлення до родини і насамперед до своїх дітей, а також тваринного й рослинного світу, що відображено в натурфілософії українців, вербалізованої ії найталановитішими письменниками. Вогонь і світло для українців - мрія, те, чого бажають, але й таке, що легко в руки не дається, а живе лише в серці.

Оскільки в кожній мові відображаються різні естетичні цінності (загальнолюдські, соціальні, національні, індивідуальні), то порівняння забезпечує й естетичну функцію мови. Йдеться не лише про поетику художньої літератури й відповідне місце в ній поетики порівнянь, але й втілення в порівняннях естетичного сприйняття світу, що виявляється в повсякденному мовленні, відображено в символіці й міфології, обрядах, традиціях і под. Саме це пояснює наявність усталених порівнянь і символів: злий як чорт, голодний як вовк, страшніший, ніж чума, купець (наречений), товар (наречена).

У порівняннях відображений код культури, причому „в природній мові код культури й номінативне членування репрезентовано в смисловому синтезі”, тобто йдеться про культурологічну функцію мовних знаків ${ }^{6}$.

До екстралінгвістичних функцій відносять й асоціативну функцію порівняння, що пов'язана 3 трьома вищезазначеними і також звернена до позамовної дійсності як предмета пізнання і до людини як суб'єкта пізнання. Асоціа-

6 В.Н. Телия, Номинативный состав языка как объект лингвокультурологии, [в:] Национально-культурный компонент в тексте и в языке: Тез. докл. Междунар. науч. конф, в 2-х тт., Минск 1994, ч.1, с. 14. 
тивні уявлення, що викликані порівнянням із березою, у білорусів і литовців, наприклад, відмінні: у білорусів і росіян — це порівняння із жіночим началом, а в литовців - 3 чоловічим ${ }^{7}$. Неоднозначні асоціації викликає у східних слов' ян i англійців порівняння жінки із свинею ${ }^{8}$. Внутрішньолінгвістичні функції, що їх виконують порівняльні засоби, такі: 1) харакеризувальна (атрибутивна, типу зачіска їжачком, білий як крейда і предикувальна, типу Iспит - цее лотерея; 2) модалізувальна (порівняння може бути вірогідним й невірогідним: вода холодна, як з холодильника - вода холодна так, ніби ї̈ цілу ніч тримали в холодильнику); 3) словотвірна (порівн. використання компонентів - -видний, -подібний у термінотворенні й під час характеризації: людиноподібний, наукоподібний, грушовидний); 4) стилетвірна (йдеться про функціонально-стильову спеціалізацію компаративних засобів i їх відмінну питому вагу в кожному зі стилів; напр., слабка концентрація, маловираженість, жорстка детермінованість експлікаторів порівняння в офіційно-діловому стилі мовлення, прикладом може слугувати використання сполучника рівно як $i$, строгий відбір компаративних засобів у науковому стилі i, навпаки, великий репертуар їх у художньому, публіцистичному й розмовному мовленні, де можна відзначити й внутрішньостильову специфіку); 5) структурувальна функція: закріплення порівняльного значення за певними граматичними формами, виникнення опозицій (напр., модально-синтаксична опозиція як-ніби, мовне й образне порівняння), формування синтаксем порівняння з фіксованою відмінковою формою (порівн.: летіти стрілою; меблі під горіх, обличчя старої баби).

Мовленнєві функції порівняння також можна розглянути в двох аспектах: комунікативному й прагматичному. Перший відображає функції порівняння в конкретному висловлюванні (дискурсі) і в конкретній мовленнєвій ситуації. Об’єктом комунікативної дії мовця є власне повідомлення. Спектр функцій порівняння на цьому рівні такий. Насамперед це ілюстративна функція, що забезпечує бачення непредметного світу як предметного (напр., репрезентація польової структури мови у вигляді концентричних кругів і таких, що пересікаються, чи сфер, порівняння пізнаних і непізнаних обсягів явища 3 видимими й підводними частинами айсбергу і под.). Порівняння, як і кожний мовний засіб, $\epsilon$ інформативним. Звідси і його друга комунікативна функція - інформативна.

Характеризувальна функція на рівні комунікації має чотири різновиди: 1) реальна відповідність порівняння зображуваному (похитнувся як n'яний); 2) гіперболізація зі знаком плюс чи мінус (дорожчий за власне життя, виглядати гірше за атомну війну); 3) евфемістична репрезентація (напр. звертання до жінки, що набрала ваги — Ти стала пампушкою); 4) ,псевдоідентифікація", нереальна відповідність, тотожність одного явища до іншого лише з одного боку (напр. Іспит - изе лотерея, але не Лотерея - це іспит).

До власне комунікативних функцій відносимо також комічно-сатиричну (напр.: Що менше продуктів для харчування, то більше продуктів для роздумів), образно-естетичну. Остання відрізняється від мовної естетичної компетенції тим, що реалізує естетичну компетенцію не соціуму, лінгвокультури,

${ }^{7}$ А. Гудавичюс, Глубинный уровень отражения культуры в лексической семантике, [в:] Исследования по семантике (сопоставительно-типологический аспект), Уфа 1993, с. 21.

${ }^{8}$ В. Н. Телия, В.А. Маслова, В.И. Шаховский, Женщина в языковой картине мира русских, белорусов, поляков, англичан, [в:] Беларуска-руска-польскае супастауляльнае мовазнауства: Матэр. другой міжнар. навук. канф. 5-6 лютаго 1992 г., Віцебск 1993, с.134.

${ }^{9}$ А. Д. Шмелев, Парадоксы идентификации, [в:] Тождество и подобие, сравнение и идентификация, Москва 1990, с. 40. 
а компетенцією чи/і задум його конкретного представника, мовної особистості автора. У цьому разі йдеться не про вираження, а про зображення.

Модалізувальна мовленнєва функція порівняння реалізується в суб'єктивному порівнянні зображеного предмета, напр.: Їй годинка здається днем, а день - тижнем.

Асоціативна функція порівняння у висловлюванні чи дискурсі сприяє формуванню цілісного образу, відповідних асоціативних зв'язків, що базуються на пресупозиції, напр. вирази Хлопещьь біг швидше за оленя чи Хлопець мчав швидше за птаха передають приблизно однаковий ступінь руху порівнювального суб'єкта, однак з художньо-естетичної точки зору більш правильним і точним $\epsilon$ перше висловлювання: порівняння бігуна з оленем дає додаткову характеристику — лякливого, беззахисного, покірного.

Інтригувальна функція (крізь образ відомого предмета формується уявлення-здогадка про невідоме) реалізується в жанрі загадки: червона дівчина в темниці - морква, біле поле з чорними птахами - книга і под.

На прагматичному рівні мовлення, де оголюється ролевий репертуар лінгвокреативного діяча, адресанта й слухача мовлення, тобто адресата, вбачаємо реалізацію трьох функцій порівняння: 1) функція самовираження мовця, коли виявляється його мовна, комунікативна, емоційна, етнічна, культурологічна, естетична та ін. види компетенцій як константи мовної особистості ${ }^{10}$ і мовленнєва поведінка як постійна змінна (стратегія й тактика самовираження); 2) емотивна функція порівняння, тобто певне посилене вираження емоцій мовцем і спонукання до вияву відповідних емоцій у слухача (Усім подарункам подарунок!); 3) етикетна функція порівняння реалізується в мовленнєво-етикетних ситуаціях, зокрема таких, як комплімент, подяка, похвала та ін.: Оленко, Ви ангел! Ти, хлопче, геній!

Схарактеризовані мовні й мовленнєві функції порівняння тісно переплетені і взаємозумовлені, в одному й тому самому імплікаторі порівняння вони можуть пересікатися, виступати в різних комбінаціях, виявляти різний ступінь атракційності тієї чи тієї форми вираження порівняння, що залежить, безперечно, від специфіки особливостей кожної конкретної мовної системи, умов функціонування, комунікативних завдань залежно від відповідних стратегій і тактик продукувача мовлення і декодувальної компетенції слухача.

У процесі міжмовного зіставлення порівняльних засобів або їх адекватного відтворення в міжкультурній діяльності, перекладі врахування усіх цих функцій і їхня взаємодія є обов'язковою умовою успішної комунікативної, лінгвокреативної діяльності, оскільки функційні межі навіть ізоморфних у міжмовному відношенні засобів можуть не збігатися. Ця неадекватність стосується як мовної системи (і відповідно функції вираження), так і мовленнєвого використання порівняльних засобів.

${ }^{10}$ T. А. Космеда, Ego i Alter Ego Tapaca Шевченка в комунікативному просторі щзоденникового дискурсу, Дрогобич 2012. 